\title{
Inhibitory Effect of Rosmarinus officinalis L. Essential Oil (Rosemary) Against Food-Borne Pathogens in a Single and in Mixed Culture
}

Jossana Pereira de Sousa (I), Kataryne Árabe Rimá de Oliveira (II), Rayanne Oliveira Lopes (II), Danilo Elias Xavier (II), Maria Lúcia da Conceição (II), Evandro Leite de Souza (II)

(I) UFPE - Universidade Federal de Pernambuco (Cidade Universitária - Recife - PE - CEP: 50670-901 ), (II) UFPB - Universidade Federal da Paraíba (Cidade Universitária - João Pessoa - PB - Brasil - CEP: 58051-900)

\section{Resumo}

Rosmarinus officinalis L. (rosemary) essential oil has a recognized antimicrobial activity against several bacterial and fungal species, but the investigation of its potential against a mixed inoculum is still scarce. Therefore, this study aimed to evaluate the inhibitory effect of rosemary essential oil against food-borne pathogens in a single and in mixed culture. The rosemary essential oil was obtained from Ferquima Industry and Commerce of Essential Oils; strains of Escherichia coli (UFPEDA 224) and Salmonella Enteritidis (UFPEDA 414) were obtained from Department of Antibiotics UFPE (Recife/PE), while the strain of Listeria monocytogenes (INCQS 7644) was obtained from the National Institute of Quality Control in Health (Rio de Janeiro/RJ). The Minimum Inhibitory Concentration (MIC) of the essential oil was determined using microdilution in broth technique as recommended by the Clinical and Laboratory Standards Institute (CLSI). For this, the strains were grown in BHI broth $\left(37^{\circ} \mathrm{C} / 24 \mathrm{~h}\right)$, with subsequent standardization of the suspensions $\left(0.5\right.$ MacFarland scale; $\left.10^{8} \mathrm{cfu} / \mathrm{ml}\right)$, with adjustment of inoculum for $5 \times 10^{5}$ $\mathrm{cfu} / \mathrm{ml}$ and preparation of the mixed inoculum in 1:1:1 rate. Then, $50 \mu \mathrm{L}$ of the mixed suspension were inoculated into microplates containing $50 \mu \mathrm{L}$ of BHI broth added $0.15 \%$ bacteriological agar and different concentrations of

\footnotetext{
Referência:

Jossana Pereira de Sousa, Kataryne Árabe Rimá de Oliveira, Rayanne Oliveira Lopes, Danilo Elias Xavier, Maria Lúcia da Conceição, Evandro Leite de Souza. Inhibitory Effect of Rosmarinus Officinalis L. Essential Oil (Rosemary) Against Food-Borne Pathogens in A Single and in Mixed Culture. In: Anais do 12ㅇ Congresso Latinoamericano de Microbiologia e Higiene de Alimentos - MICROAL 2014 [= Blucher Food Science Proceedings, num.1, vol.1]. São Paulo: Editora Blucher, 2014.

DOI 10.5151/foodsci-microal-329
} 
the essential oil $(10-320 \mu \mathrm{l} / \mathrm{ml})$. After incubation $\left(37^{\circ} \mathrm{C} / 24 \mathrm{~h}\right)$, checking the bacterial growth was performed by adding $20 \mu \mathrm{L}$ of Resazurin $(0.01 \%)$. MIC was considered the lowest dilution of the essential oil causing no microbial growth. The MIC value for E. coli and S. Enteritidis was $80 \mu \mathrm{l} / \mathrm{ml}$, and for L. monocytogenes was $20 \mu \mathrm{l} / \mathrm{ml}$. When tested in mixed inoculum, the MIC value was $80 \mu 1 / \mathrm{ml}$. These results indicate a significant inhibitory effect of rosemary essential oil and that the type of inoculum did not affect the MIC value, which were the same against E. coli, S.

Enteritidis and mixed inoculum. The study of the inhibitory effect of essential oils using mixed inocula provides more realist information about their efficacy when applied in food matrices, since when the bacteria are tested in mixed culture are imposed growth conditions that may influence the response of microorganisms to the action of antimicrobial compounds. The data presented in this study also reinforce the possible use of rosemary essential oil as an antimicrobial by food industry in order to improve the microbiological quality of products.

Palavras-Chave: Essential oil, Food-borne pathogens, Mixed inoculum, Rosemary

\section{Agência de Fomento:}

